\title{
VERPLEEGKUNDIGES EN PASIëNTE SE BELEWENIS VAN GESAMENTLIKE GESONDHEIDSDIENSLEWERING AAN ALLE BEVOLKINGSGROEPE IN 'N HOSPITAAL
}

\author{
M Poggenpoel, H Uys, A Botes, C Dörfling, M Greeff, \\ E Gross, M Müller en A Nolte
}

\section{OPSOMMING}

Die hospitaalbestuur van 'n gemeenskapshospitaal in Gauteng, is op kort kennisgewing genoodsaak om gesamentlike gesondheidsdienste aan alle bevolkingsgroepe te voorsien. In die verlede is verskillende gesondheidsdienste gelewer aan elke bevolkingsgroep. Die integrasie van die gesondheidsdienslewering was 'n skielike verandering. 'n Paar navorsingsvrae het ontstaan, naamlik: hoe beleef verpleegkundiges en pasiënte hierdie verandering, en hoe kan hulle gehelp word om aan te pas by die verandering. Die navarsingsdoelstellings was tweeledig, naamlik: die verkenning en beskrywing van verpleegkundiges en pasiënte se belewenis van gesamentlike gesondheidsdienslewering aan alle bevolkingsgroepe en gebaseer op die resultate om aanbevelings te maak om hulle te help met aanpassing by die gekombineerde gesondheidsdienslewering. ' $n$ Verkennende, beskrywende en kontekstuele navorsingsontwerp is gevolg. Vertrouenswaardigheid was verseker deur die toepassing van Guba se benadering. Fenomenologiese en individuele fokusonderhoude was gevoer met veertig verpleegkundiges en pasiënte wat doelgerig geselekteer is. Veldnotas was geskryf na voltooiing van elke onderhoud. Die getranskribeerde data was geanaliseer deur gebruikmaking van die gekombineerde metodes van Giorgi en Kerlinger. Resultate was bespreek en 'n literatuurkontrole voltooi. Die belangrikste gevolgtrekking wat gemaak was, is: daar was ' $n$ onvoldoende administratiewe struktuur in die hospitaal as gevolg van die onvoldoende voorbereiding vir die gesamentlike gesondheidsdienslewering vir alle bevolkingsgroepe; die blankes se persepsie van verskillende bevolkingsgroepe is gebaseer op ' $n$ etnosentriese Westerse benadering. Dit lei daartoe dat hulle kultuurskok ervaar wat gevoelens van woede/frustrasie, angs en hartseer tot gevolg het; die bereidwilligheid van anderskleuriges om by gesamentlike gesondheidsdienslewering aan te pas lei tot hulle belewenis van vreugde; daar bestaan kommunikasieprobleme tussen bevolkingsgroepe omdat hulle nie in hulle eie taal kan kommunikeer nie sowel as verskille in kommunikasiestyle; blanke verpleegkundiges en pasiënte se geverbaliseerde Christelike mensbeskouing en waardes is nie kongruent met hulle bevooroordeelde persepsie van mense van ander bevolkingsgroepe en kulture nie en die verskillende bevolkingsgroepe ken nie mekaar se leefwêrelde nie en dit lei tot vooroordele wat oop kommunikasie blokkeer. Verskeie aanbevelings is gemaak gebaseer op hierdie gevolgtrekkings.

\section{ABSTRACT}

In a community hospital in Gauteng, the hospital management had, on short notice, to provide combined health services to all population groups. In the past different health services were delivered to each population group. The integration of health service delivery was a sudden change. Based on this, research questions arose, namely: how do nurses and patients experience this change, and how could they be assisted to adjust to the change. The research objectives were twofold, namely: to explore and describe nurses and patients' experience of combined health delivery to all population groups and based on the results to make recommendations to assist them with adjustment to a combined health delivery system. An exploratory, descriptive and contextual research design was followed. Trustworthiness was ensured by applying Guba's approach. Phenomenological and individual focus interviews were conducted with forty nurses and patients who were selected purposively. Field notes were written after completion of each interview. The transcribed data was analysed by using Giorgi's and Kerlinger's methods combined. Results were discussed and a literature control completed. The most important conclusions reached were: there was an insufficient administrative structure in the hospital as a result of insufficient preparation for the combined health service delivery for all population groups; the whites' perception of different populations groups is based on an ethnocentric Western approach. This led to their experience of culture shock that resulted in feelings of anger/frustration, fear and-sadness; the willingness of other populations groups to adjust to combined health service delivery led to their experience of happiness; there exists communication problems between population groups because of their not being able to communicate in their own language and the difference in communication styles; the verbalised Christian viewpoint and values of whites nurses and patients are not congruent with their prejudiced perception of people of other population groups and cultures, and the different population groups do not know each other's lifeworlds and that leads to prejudices that block open communication. Several recommendations were made based on these conclusions. 


\section{INLEIDING}

Vanaf 1990 het daar snelle verandering in Suid-Afrika begin plaasvind met die wegbeweeg van die politieke apartheidstelsel na 'n demokratiese geïntegreerde samelewing. Hierdie verandering het ook in die gesondheidsdienste begin plaasvind (Kotzé, 1990:76). Die lewering van aparte gesondheidsdienste aan verskillende bevolkingsgroepe en gepaardgaande fragmentasie in gesondheidsdienste is afgeskaf. Die nuwe benadering behels dat daar nou ' $n$ gesamentlike gesondheidsdiens aan alle bevolkingsgroepe gelewer sal word en dat daar een gesondheids-beleidstruktuur sal wees. Omdat daar juis in die verlede ' $n$ apartheidstelsel bestaan het, sal wanneer verwys word na alle bevolkingsgroepe in hierdie artikel, voormalige rasindeling gebruik word, naamlik blankes, swartes, Indiërs en kleurlinge. Waar na laasgenoemde drie groepe as anderskleuriges verwys word.

Die verandering in benadering tot gesondheidsdienslewering beïnvloed die hospitaal-omgewing en die verpleegkundiges en pasiënte wat daarin in interaksie met mekaar tree. Verpleegkundiges en pasiënte word gekonfronteer met kulturele diversiteit. ' $n$ Hospitaal kan beskou word as ' $n$ gemeenskap en die individue (verpleegkundiges, pasiënte en ander) wat hierdie gemeenskap uitmaak, se gesondheid beïnvloed en ook die vermoë om kwaliteit gesondheidsdiens te verskaf.

As verpleegkundiges en pasiënte nie paraat is om die uitdaging van ' $n$ kulturele diverse gesamentlike gesondheidsdiensleweringsopset die hoof te bied nie, kan dit lei tot destruktiewe reaksies soos etnosentrisme, verwerping, 'n lae produktiwiteit, swak gehalte verpleging wat dan weer die gehalte gesondheidsdiens wat die hospitaal lewer negatief beïnvioed (Butrin, 1990:92-113). Dit is dus noodsaaklik dat aandag geskenk sal word om verpleegkundiges en pasiënte te oriënteer tot aanvaarding van kulturele diversiteit in gesamentlike gesondheidsdienslewering aan alle bevolkingsgroepe

\section{PROBLEEMSTELLING}

In 'n gemeenskapshospitaal in Gauteng het die hospitaalbestuur op kort kennisgewing opdrag gekry om gesamentlike gesondheidsdienslewering aan alle bevolkingsgroepe te bied. Volgens die hospitaalbestuur was dit 'n skok vir beide personeel en pasiënte aangesien geen voorbereidingswerk hiervoor getref is nie. Veral verpleegkundiges en pasiënte het moeg en gefrustreerd voorgekom. Die hospitaalbestuur het ons navorsingspan genader om vas te stel waar probleme met die lewering van gesamentlike gesondheidsdienste voorkom en aanbevelings te maak hoe verpleegkundiges en pasiënte gehelp kan word om by die verandering aan te pas. Dit is dus noodsaaklik om vas te stel hoe beleef verpleegkundiges en pasiènte die gesamentlike gesondheidsdiens- lewering in die hospitaal aangesien geen gedokumenteerde inligting hieroor bestaan me.

\section{DOELSTELLING EN TEORETIESE RAAMWERK}

Die doelstelling van hierdie navorsing was om eerstens verpleegkundiges en pasiënte van ' gemeenskapshospitaal se belewenis van 'n gemeenskaplike gesondheidsdienslewering aan alle bevolkingsgroepe te verken en te beskryf en tweedens op grond van resultate, aanbevelings te maak om hulle te help om hulle aanpassing by ' $n$ gesamentlike gesondheidsdienslewerings- opset te fasiliteer.

Die Verplegingsteorie vir Mensheelheid (Oral Roberts University, 1990-1992:136-142; Randse Afrikaanse Universiteit: Departement Verpleegkunde, 1992:36-41) is gebruik as ' $n$ teoretiese raamwerk om die resultate van die navorsing te bespreek. Hierdie teorie beskou ' $n$ gemeenskap as ' $n$ identifiseerbare groep mense wat 'n gemeenskaplike interaktiewe wyse van interaksie en/of geografiese gebied deel.

In hierdie navorsing verwys gemeenskap na 'n hospitaal in Gauteng en die groep mense na pasiënte en verpleegkundiges wat met mekaar in interaksie is. Die hospitaal se omgewing bestaan uit veskillende dimensies, naamlik fisiese, psigiese, sosiale en geestelike dimensies wat die gesondheidstanus en dus die kwaliteit gesondheidsdienslewering van die hospitaal bepaal.

Die fisiese dimensie verwys na al die strukturele en funksionele aspekte van die hospitaal, en die psigologiese dimensie verwys na al die intellektuele, emosionele en wilsaspekte/prosesse in die hospitaal. Die sosiale dimensie verwys na die interaksies tussen mense as hulpbronne. Die geestelike dimensie verwys na betekenisvolle geestelike aspekte of gebeurtenisse in die hospitaal se omgewing en sluit waardes, gelowe, norme, etiese beginsels, godsdiens, sin en betekenis in die lewe, sowel as verhoudinge met andere en God in.

\section{NAVORSINGSONTWERP-EN METODE}

'n Verkennende, beskrywende en kontekstuele navorsingsontwerp was gevolg (Mouton \& Marais, 1990:45,46,53). Fenomenologiese (semi-gestruktureerde) (Burns \& Grove, 1987:81-84) en fokusonderhoude (gestruktureerd) (Polit \& Hungler, 1989:194) is gevoer en veldnotas geskryf na elke onderhoud (Polit \& Hungier, 1989:207). Dié ingesamelde data was gebruik om aanbevelings te maak om verpleeg. kundiges en pasiënte te help om hulpbronne te mobiliseer om sodoende hulle aanpassing by in gesamentlike gesondheidsdiensleweringopset te fasiliteer.

\section{STEEKPROEF}

Die steekproefpopulasie het bestaan uit verpleegkundiges en pasiënte in ' $n$ gemeenskapshospitaal in Gauteng. Kriteria vir insluiting van pasiënte by die navorsing was dat hulle agttien jaar of ouer moet wees; kan kommunikeer sonder enige liggaamlike beperkinge van pyn of pynmedikasie of psigiese versteuring wat hulle bewussyn kan aantas; verteenwoordigend moet wees van alle behandelingsareas binne die hospitaal; Afrikaans of Engels magtig moet wees (dit is die tale waarin die navorsers kan kommunikeer); van alle bevolkingsgroepe moet wees, en vrywillig deelneem. Die volgende is behandelingsareas wat uitgesluit was uit die steekproef aangesien pasiënte nie voldoen het aan die kriteria vir navorsing nie: kritiese-sorgeenhede, operasiesale, dialise-eenheid, pediatriese eenhede en ongevalle.

Kriteria vir die insluiting van verpleegkundiges was dat die verpleegkundiges: op die diensstaat van die betrokke hospitaal is; verteenwoordigend is van die hoofkategorieë verpleegpersoneel (verpleegkundiges, hoofverpleegkundiges en verpleegdiensbestuurders); Afrikaans of Engels magtig is, en vrywillig deelneem. Al die eenhede wat ingesluit kon wees, was eerstens geïdentifiseer en geklassifiseer volgens behandeling/dissipline wat gebied word. Een mediese en een chirurgiese eenheid was ewekansig (Burns \& Grové, 1987:209-211; Creswell, 1994:126) ingesluit in die steekproef aangesien dit die enigste eenhede was waar meer as een per dissipline voorgekom het. Al die ander eenhede was doelgerig (Bums \& Grove, 1987:218-119; Creswell, 1994:148) geselekteer omdat hulle voldoen het aan die gestelde kriteria. Hiema was die hoofverpleegkundiges en verpleegdiensbestuurders van die geselekteerde eenhede geidentifiseer. Die verpleegkundiges en pasiënte van die steekproef-eenhede was doelgerig ingesluit by die navorsing. Die eenhede se hoofverpleegkundiges het as tussengangers opgetree om die verpleegkundiges nonselektief in te sluit by die navorsing, terwyl die verpleegkundiges weer as tussengangers opgetree het om pasiënte nonselektief in te sluit.

Onderhoude was gevoer met die kategorieë verpleegkundiges en pasiënte tot die data versadig is soos gedemonstreer deur herhalende temas. Vier-en-twintig verpleegkundiges en sestien pasiënte het deeigeneem in dié navorsing.

\section{GELDIGHEID EN BETROUBAARHEID}

Guba (in Lincoln \& Guba, 1985:289-331; in Krefting, 1991:214-222) se kriteria vir versekering van vertrouenswaardigheid in kwalitatiewe navorsing was gebruik om die geldigheid en betroubaarheid van hierdie 
TABEL 1: STRATEGIEË OM VERTROUENSWAARDIGHEID TE VERSEKER

\begin{tabular}{|c|c|c|}
\hline STRATEGIEEE & KRITERIA & TOEPASSING \\
\hline Geloofwaardigheid & $\begin{array}{l}\text { Langdurige en verskeidenheid } \\
\text { veldondervinding } \\
\text { Refleksiwiteit } \\
\text { Triangulering } \\
\text { Ledekontrole } \\
\text { Ewegroepsevaluering } \\
\text { Onderhoudtegniek } \\
\text { Outoriteit van navorser } \\
\text { Strukturele koherensie }\end{array}$ & $\begin{array}{l}\text { Navorsers verskeie jare betrokke in } \\
\text { hospital. Drie maande voorbereiding } \\
\text { vir navorsing. Veertig fenomenologi- } \\
\text { ese en fokusonderhoude, veldnotas. } \\
\text { Dataverwerking oor ses maande. } \\
\text { Veldnotas is gemaak. } \\
\text { Veertig fenomenologiese onderhoude. } \\
\text { verskillende behandelingsareas. vyf } \\
\text { onderhoud voerders, twee onaf- } \\
\text { hanklike kodeerders, Giorgi \& Kerlin- } \\
\text { ger se metodes van data-analise } \\
\text { gekombineer, literatuur kontrole. } \\
\text { Oudiobandopnames teruggespeel aan } \\
\text { pasiente, opvolgonderhoude met vier } \\
\text { verpleegkundiges, iiteratuurkontrole. } \\
\text { Vyi navorsers en twee onathanklike } \\
\text { kodeerders met data-analise. } \\
\text { Inoefening van onderhoudvoering. } \\
\text { Loodsstudie met twee persone om } \\
\text { struikelblokke in wyse van onderhoud- } \\
\text { voering uit te skakel. } \\
\text { Projekleier het vorige ervaring van } \\
\text { kwalitatiewe navorsing. Voorbereiding } \\
\text { van navorsers en kodeerders. } \\
\text { Fokus op belewenis deur ver- } \\
\text { pleegkundiges en pasiënte van ge- } \\
\text { samentlike dienslewering. } \\
\text { Inkonsekkwenthede in data uitgeklaar. } \\
\text { Resultate word binne vTMH bespreek. } \\
\text { Riglyne gebaseer op resultate. }\end{array}$ \\
\hline Oordraagbaarheid & $\begin{array}{l}\text { Genomineerde steekproef } \\
\text { Vergelyking van steekproef met demo- } \\
\text { grafiese data } \\
\text { Digte beskrywing }\end{array}$ & $\begin{array}{l}\text { Ewekansige sowel as doelgerigte } \\
\text { steekproetheming soos gepas in hier- } \\
\text { die navorsing. } \\
\text { Alle behandelingseenhede, verskil- } \\
\text { lende kategorieé verpleegkundiges en } \\
\text { alle bevolkingsgroepe pasiente wat } \\
\text { voldoen aan ksiteria is ingesluit. } \\
\\
\text { 'n Volledige besknwing van metodolo- } \\
\text { gie, literatuurkontrole en woord vir } \\
\text { woord aanhalings vit onderhoude } \\
\text { word gegee. }\end{array}$ \\
\hline Vertroubaarheid & $\begin{array}{l}\text { Vertroubaarheidsoudit } \\
\text { Digte beskrywing van navorsingsme- } \\
\text { tode } \\
\text { Triangulering } \\
\text { Ewegroepevaluering } \\
\text { Kodeer-herkodeerprosedure }\end{array}$ & $\begin{array}{l}\text { Vrae is getoets in voorstudie, 'n data- } \\
\text { analiseprotokol is gebruik, wee onal- } \\
\text { hanklike kodeerders. } \\
\text { Navorsingsmetodolo gie volledig besk- } \\
\text { yt. } \\
\text { Soos voorteen bespreek. } \\
\text { Navorsingsprotokol bespreek met na- } \\
\text { vorsingspan. Twee onafhanklike } \\
\text { kodeerders. } \\
\text { Konsensusbesprekings tussen navors- } \\
\text { ers en mee onafhanklike kodeerders. }\end{array}$ \\
\hline Bevestigbaarheid & $\begin{array}{l}\text { Bevestigbaaneidsoudit } \\
\text { Triangulering } \\
\text { Refleksiwiteil }\end{array}$ & $\begin{array}{l}\text { Terugspeet van oudicbandopnames } \\
\text { aan pasiénte, opvolgonderhoude met } \\
\text { verpleegkundiges, twee onafhanklike } \\
\text { kodeerders. } \\
\text { Soos voorheen bespreek } \\
\text { Veldnotas. }\end{array}$ \\
\hline
\end{tabular}

navorsing te verseker. Die vier kriteria vir vertrouenswaardigheid is: waarheidswaarde; toepasbaarheid; konsekwentheid en neutraliteit. Die waarheidswaarde was verseker deur strategieë van geloofwaardigheid toe te pas en toepasbaarheid deur strategieë van oordraagbaarheid toe te pas. Konsekwentheid was verseker deur strategieë van vertroubaarheid toe te pas en neutraliteit deur strategieè van bevestigbaarheid. Tabel 1 dui aan hoe dié strategieë toegepas was in die navorsing om vertrouenswaardigheid te verseker.

\section{DATA-INSAMELING}

Fenomenologiese (semi-gestruktureerd) (Burns \& Grove, 1987:81-84; Kvale, 1985:171-196) en fokusonderhoude (gestruktureerd)(Polit \& Hungler, 1989:194) was gevoer. Die navorsers het beide metodes van onderhoudvoering gebruik met elke onderhoud wat gevoer is. Daar is met die fenomenologiese onderhoud begin deur te vra "Hoe ervaar u dit om saam met alle bevolkingsgroepe in hierdie hospitaal te wees?/How do you experience being with all population groups in this hospital?". Nadat 'n respondent ten volle sy/haar belewenis geverbaliseer het, het die navorser voortgegaan met 'n fokusonderhoud waar spesifieke vrae gestel was oor die verskillende dimensies in die hospitaalomgewing as die respondent nie belewenis in alle dimensies weergegee het nie. Elke onderhoud was op oudioband opgeneem en het van dertig minute tot een-en-'n-half uur geduur. Kommunikasietegnieke soos parafrasering, opsomming, reflektering, minimale respondering en opklaring was gebruik om respondente aan te moedig om vrylik te kommunikeer (Wilson \& Kneisl, 1992:149-151). Veldnotas (Polit \& Hungler, 1989:207) was onmiddellik na elke onderhoud geskryf om die onderhoudsituasie en die navorser se indrukke te beskryf. 'n Voorstudie was uitgevoer deurdat onderhoude gevoer is met twee individue ('n verpleegkundige en 'n pasiënt) wat voldoen het aan die kriteria van die navorsing. Hierdie voorstudie was uitgevoer om uit te klaar of die geformuleerde enkelvraag wel die respondente se belewenis van die gesamentlike gesondheidsdienslewering aan alle bevolkingsgroepe ontlok.

\section{DATA-ANALISE}

Die getranskribeerde data is deur vyf navorsers en twee verpleegkundiges met doktorsgrade in verpleegkunde onafhanklik van mekaar geanaliseer.

Giorgi (1985:10-19) en Kerlinger (1986:477) se metodes vir data-analise was gekombineer en skriftelik aan die kodeerders voorsien as 'n protokol. Die stappe wat in die data-analise gevolg was, is:

- Data (al die getranskribeerde onderhoude en veldnotas) was deur die navorsers en 
kodeerders onafhanklik van mekaar gekodeer. Kodeerders het "tussen hakies plaas" (die plaas van vooropgestelde idees tussen hakies) en "intuiltering" (fokus op respondente se belewenis van gesamentlike gesondheidsdienslewering aan alle bevolkingsgroepe) as denkwyses gebruik toe hulle die transkripsies en veldnotas vir die eerste maal deurgelees het. Die universum het bestaan uit al die transkripsies van die onderhoude en veldnotas.

- Kodeerders (navorsers en twee verpleegkundiges met doktorsgrade) het die hoof-kategoriee verteenwoordig in die universum geïdentifiseer. Hierdie kategorieë was gereflekteer binne die verskillende dimensies van die hospitaal se omgewing: fisies, psigologies, sosiaal, geestelik en die kenmerkende wyses van interaksie tussen die dimensies.

- Kodeerders het die eenhede van betekenis wat verband hou met die geidentifiseerde hoofkategorieë onderstreep.

- Die eenhede van betekenis was ingedeel onder die hoofkategorieë.

- Subkategorieë was binne die hoofkategorieë geïdentifiseer.

- Verhoudings tussen hoof-en subkategorieë was geïdentifiseer en as temas weergegee.

- Konsensusbesprekings het tussen die navorsers en onafkhanklike kodeerders plaas-gevind.

'n Literatuurkontrole was uitgevoer om ooreenkomste, verskille en bydrae tot navorsing vas te stel.

\section{RESULTATE EN BESPREKING}

Die bespreking van resultate geskied op grond van Tabel 2. Direkte aanhalings van respondente en toepaslike literatuurkontrole word aangebied om die bespreking te ondersteun.

Die syfers in Tabel 2 se funksie is om aan te dui hoeveel respondente (verpleegkundiges en pasiènte) soortgelyke belewenisse en menings geverbaliseer het. Dit word gebruik om prioriteite te stel vir aanbevelings van dié navorsing. In die bespreking van die resultate word wel van die uitgediende terme "blank" en "anderskleurig" gebruik gemaak omdat daar verskille in die twee groepe se belewenisse en menings was. Die gebruik van die term "Westers" word ook aan "blankes" gekoppel, ter wille van hierdie bespreking.

Vervolgens word die resultate van die navorsing bespreek binne die raamwerk van die verskillende dimensies in die hospitaalomgewing en die kenmerkende interaksie tussen die dimensies.

\section{TABEL 2: VERPLEEGKUNDIGES EN PASIENTTE SE BELEWENIS VAN GESAMENTLIKE GESONDHEIDSDIENSLEWERING AAN ALLE BEVOLKINGSGROEPE (VERPLEEGKUNDIGES $=V$; PASIËNTE $=P$ )}

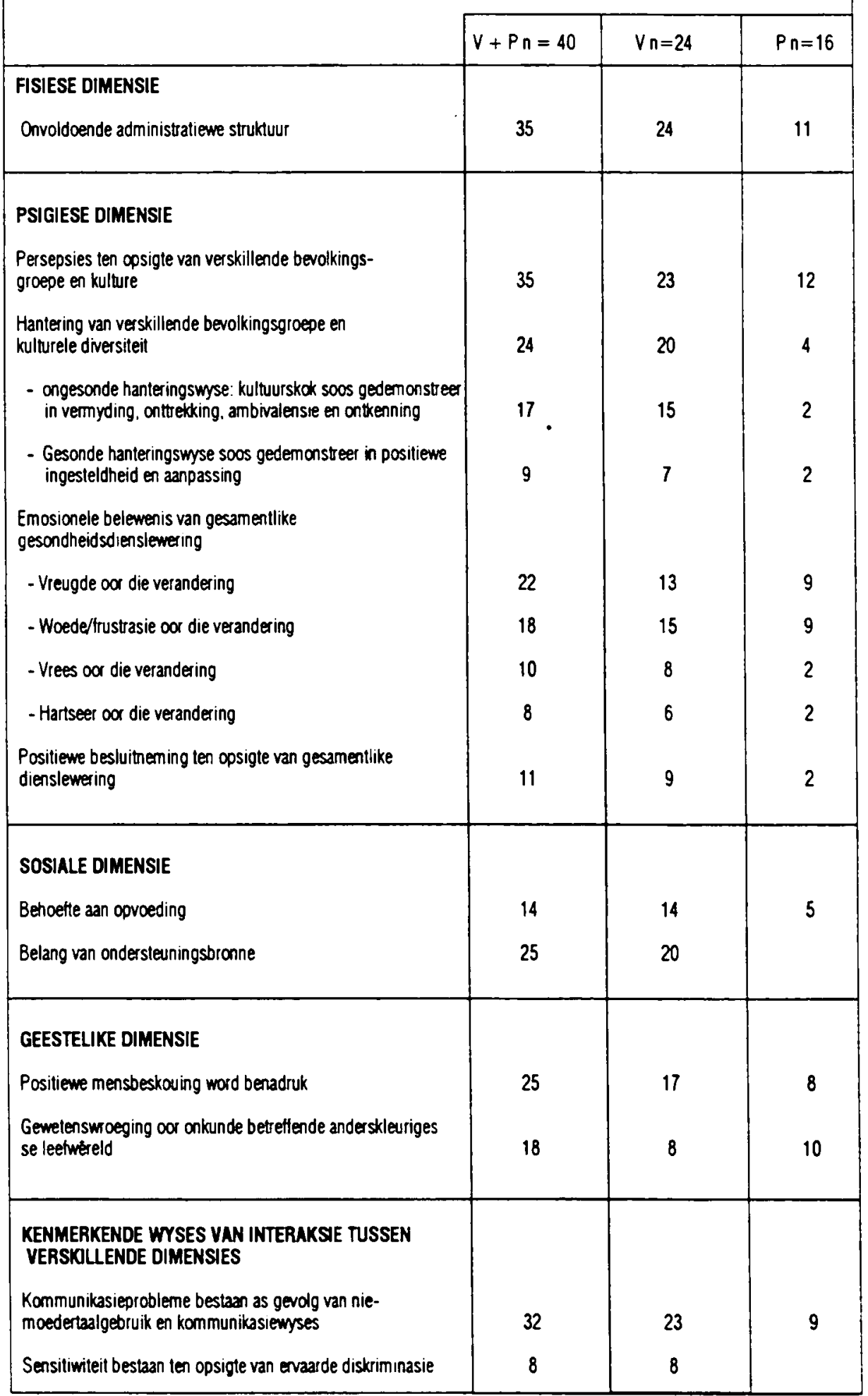

\section{FISIESE DIMENSIE VAN HOSPITAALOMGEWING}

Die respondente beleef dat daar ' $n$ onvoldoende administratiewe struktuur in die hospitaal is. Die bestuurstelsel word as deurmekaar beleef: "Dit was chaos, ons was daar onder gewees by die grootbase vanoggend en almal sê net vir jou 'maar almal het hierdie drukte" "en "Dit is te deurmekaar, ek weet nie, want ' $n$ mens is mos nie gewoond aan so "n hospitaal nie." 'n Tekort aan personeel en die gepaardgaande werksdruk word negatief beleef: “... skielik "n geweldige werkslading", "Op die oomblik is dit nie vir my altyd baie lekker nie, omdat my werkslas verhoog en ek moet meer goed tuis gaan doen en dan kry ek minder tyd om met my kinders deur te bring" en "I have already mentioned the shortage of staff. So at the end of the day you are very exhaustod, you see, and it is also affecting one's social life." 
Skynbaar is daar ook nie voorsiening gemaak vir beleidsdokumente wat deur alle verpleegkundiges verstaan kan word nie en dit dra by tot die belewenis dat die gesamentlike gesondheidsdienslewering ongeorden is: "All the documents and the policies and the Acts, everything is in Afrikaans and that you have to register down in ... so that was my problem, you know, getting to understand".

Skynbaar onbeplande gesondheidslewering aan alle bevolkingsgroepe dra by tot die respondente se belewenis soos reeds bespreek. Dörfling (1987:38) wys daarop dat indien verandering te vinnig plaasvind en ontwrigtend op personeel inwerk, voel personeel onveilig en vrees verlaging van standaarde (Drennan, 1987:9,11). Veranderinge in die samestelling van " $n$ organisasie soos " $n$ hospitaal bring nie net verandering in personeelsamestelling en dienslewering mee nie, maar ook in waardes, filosofieë en tradisies. Hierdie kultuurverandering moet volgens Dörfling (1987:38) stapsgewys plaasvind. Verder is Gillies (1982:171-172) ook van mening dat uitbreiding in dienste sonder personeelvoorsiening oorlading, spanning en demotivering in die hand kan werk.

\section{PSIGIESE DIMENSIE VAN HOSPITAALOMGEWING}

Respondente verbaliseer persepsies ten opsigte van verskillende bevolkingsgroepe en kulture, hoe hulle kulturele diversiteit hanteer. emosionele belewenisse van gesamentlike gesondheidsdienslewering en positiewe besluitneming ten opsigte van gesamentlike diens-lewering.

\section{Persepsies ten opsigte van verskillende bevolkingsgroepe en kulture.}

Die resultate van hierdie navorsing dui op verskillende vooroordele van verpleegkundiges en pasiënte teenoor mekaar op grond van persepsies oor bevolkingsgroepe en kulture wat nie dieselfde as hulle s'n is nie. Respondente (blanke verpleegkundiges) beleef dit dat anderskleurige kollegas se opleiding nie op standaard is nie: "Die manier warop hulle opgelei word, verskil hemels-breed van ons, dit het ek agter gekom, daar is net half ' $n$ 'no caring' houding in verband met hulle werk en in verband met alles wat hulle doen" en "Dit het gegaan oor basiese verpleegkundige standaarde en ons het wel gevind hierdie mense is geregistreer, maar hulle voldoen nie werklik aan spesifieke standaarde nie ... ek verwys hier spesifiek na die bestek van praktyk".

Die literatuur ondersteun dié bevinding dat daar vooroordele ten opsigte van mense van ander bevolkingsgroepe en kulture bestaan en skryf dit toe aan onkunde. Die apartheidsbeleid sedert 1960 het volgens Boonzaaier (1988:79) nie net verseker dat die bevolking in Suid-Afrika in etniese groepe verdeel is nie, maar ook dat hulle apart ontwikkel, opgelei word en geleef het. Dit wat die "ander" weet of doen, was onbekend en met agterdog bejeèn. Kultuur wat alomvattend is, skep ook eie grense van klas, etnisiteit, ras en geslag en hierdie grense word deur die groep gehandhaaf (Boonzaaier, 1988:27). Groepintegrasie buite hierdie grense word aanvanklik gekenmerk deur agterdog, vergelyking, onveiligheid en bekommernis dat "iets" verlore sal gaan (Boyle, 1989:10; Rambo, 1984:53). Rambo (1984:350) meen dat die vergelyking van standaarde dikwels vanuit " $n$ Westerse oogpunt geskied en die term "West is best" word hieraan gekoppel. Alhoewel verpleegopleiding geskoei is op dieselfde basiese riglyne ervaar swart verpleegkundiges hulle opleiding problematies aangesien dit plaasvind in ' $n$ "vreemde" taal en geskoei is op Westerse beginsels (Luthuli, 1992:30). Alternatiewe wyses van opleiding behoort ondersoek te word. Friedman (1995) in 'n referaat gelewer, beveel 'n gemeenskapsgebaseerde onderrigbenadering aan vir alle gesondheidsdienswerkers waar hulle binne klinieke in die gemeenskap deur ervaringsleer beginsels en vaardighede van primêre gesondheidsorg bemeester. Verder is respondente (blanke verpleegkundiges) van mening dat hulle siening van tyd verskil van dié van hulle anderskleurige kollegas: "... hulle begrip van tyd is vir my een van die grootste probleme ... sy kan nie verstaan hoekom jy nou so onsteld is dat sy laat is". Giger (1991:49) beweer dat siening van tyd kultureel verskil. Die meeste diversiteit word gevind tussen horlosietyd en sosiale tyd. Waar eersgenoemde streng minuut georiënteer is, is laasgenoemde ingestel op gebeure. Hierdie siening koppel ook met die ingesteldheid aangaande afsprake en in die geval van hospitaalpersoneel, aandienstye aangesien min waarde aan tyd as sodanig geheg word (Kozier, 1992:359). Kotze (1993:15 \& 16) meen dat blankes meer horlosietyd gerig is en dat anderskleuriges meer ingestel is op gebeure/verhoudings en dus nie veel waarde heg aan stiptelikheid nie.

Die anderskleurige verpleegkundiges beleef dat hulle as minderwaardig beskou word deur blanke kollegas en pasiënte, sowel as kollegas wat mans is: "I was a bit frustrated because they were frustrating me, but I just told myself that with time people will learn to accept me as a registered nurse"; "... sê die pasiënte nooit goed vir ons nie ... hulle het seker nie vertroue in ons as swart susters nie" en "... the males are superior to the females and if you have a male sister in the ward, for instance, he may not take orders from a female sister like others, because to him you are a female and inferior".

Blanke yerpleegkundiges beleef ook dat anderskleurige pasiënte higiënies swak versorg is, swak tafelmaniere het en swak opgevoed is ten opsigte van die gebnuik van badkamergeriewe: "As ek kyk hoe vuil party van hulle hier aankom en ek dink dit is absolute onkunde oor higiëne ..."; " ... baie van hulle ken glad nie ' $n$ toilet nie en gebruik sommer die badkamervloer of die bad", en " ... the hygiene is non-existent in some of these patients. We have to fight with them to get them in the bath". Volgens Rambo (1984:350) en Giger (1991:120) is individualisme en hoë higiëniese standaarde kenmerke van Westerse kulturele ingesteldheid. Hieronder tel eet- en toiletgewoontes wat dikwels beoordeel word vanuit die verpleegstandaarde wat in ' $n$ eenheid gestel word en op ander geforseer word (Leininger, 1991:36). Dit is dus ook so dat van die pasiënte van informele huisvestigingsgemeenskappe kom waar daar nie sanitêre geriewe of krane beskikbaar is nie en die pasiënte nie blootgestel was aan volledige badkamergeriewe nie en dan nie weet hoe om dit te benut nie (Poggenpoel, et. al., 1994:133)

Die blanke verpleegkundiges spreek ook onkunde uit oor anderskleuriges se kultuur en leefwêreld en skryf dit toe aan die apartheidsbeleid wat vir 'n paar dekades toegepas is:

“... ek het nie regtig besef hoe hierdie mense regtig buite lewe nie, Dit was vir my baie vreemd gewees"; "Dit was iets wat heeltemal buite my verwysingsraamwerk bestaan het. Vir my, het ek die Kleurling of die Swarte in die straat gesien, ek het by kom verbygeloop, ek het hom nie eers gegroet nie"; “... die swart bevolking het in een hoekie grootgeword en ek het in " $n$ ander hoekie grootgeword ...", en "... It is difficult in the beginning, because you do not know how to treat somebody you have not, that has not been your neighbour, you know".

Blanke respendente verwys ook na die ongemak wat hulle beleef as groot groepe besoekers by anderskleurige pasiënte kom besoek_aflê: "... hulle vervoer is nie so geredelik beskikbaar nie en hulle kom in " $n$ redelike groot groep by die pasiënt besoek aflê. Dit is nogal "n probleem, veral naweke"; "... hulle in hierdie oormassas miskien hulle pasiënt wil besoek, wat dan ' $n$ probleem veroorsaak"; " ... die swartes kom in hulle hordes ...", en "... wit besoekers voel bedreig". (Kotze (1993:14 \& 15) meen dat swartmense meer groepsgeoriënteerd is in teenstelling met die blankes se Westerse individualisme. Hulle ondersteun mekaar ook binne die groep omdat hulle kollektiewe verantwoordelikheid vir mekaar neem (Giger, 1991:49; Boonzaaier, 1988:153; Keesing, 1981:301). Dit is duidelik uit die voorafgaande skrywers se werk dat blankes uit hulle eie verwysingsraamwerk nie hou van die groot groepe anderskleuriges nie omdat dit hulle bedreig.

Blanke respendente meen ook dat anderskleuriges te hard met mekaar prant: "... hulle is seker verbaal, hulle is meer hoorbaar" en "... hulle praat kliphard met mekaar en dit is so steurend, u weet, en ek het nie verstaan waaroor hierdie kliphard pratery gaan nie". Kotze (1993:8) wys daarop dat in teenstelling met blankes se beskouing dat ' $n$ persoon goeie maniere het as hy in die openbaar sag praat, die teenoorgestelde waar is vir swart mense. 
Hantering van verskillende

bevolkingsgroepe en kulturele diversiteit

Dit blyk uit die navorsing dat respondente verskillende die verskillende bevolkingsgroepe en kulturele diversiteit op ongesonde of gesonde wyses hanteer. Die engesonde wyse van hantering lei tos respondente se belewenis van kultuurskok soes gedemonstreer in vermyding. onttrekking ambivalensie en entkenning: “... ek het verstom gestaan, geskok gestaan, omdat ek nie bewus was van hierdie leefwyses nie"; “... ek kan nie verstaan hoekom is jy so ontsteld dat sy laat is ... vir die saalsusters traumaties ... hulle haat dit en word kwaad vir hierdie mense", en "Like patients having to share the same rooms with white patients, sometimes feel offended. They find it quite strange, you know. I mean, like suddenly you are imposing something completely different onto them".

Respondente (blanke pasiënte) verbaliseer ook dat hulle eerder interaksie met anderskleurige besoekers sal vermy: "I would rather stay out than be with, you know, all these people standing around". Respondente (blanke pasiënte) verbaliseer verder dat hulle hulle eerder onttrek van anderskleuriges: "We do basically keep to ourselves"; “... the blacks will keep to themselves and the whites to themselves", en "... jy nie geselskap het nie".

Blanke verpleegkundiges beleef ambivalensie in hierdie situasie: "Ek meen, mens moet dit begin aanvaar ... Daar is dingetjies waaraan jy gewoond moet raak", en "Maar ek geniet dit. Dit is interessant so tussen die frustrasie deur en ek dink later sal dit beter gaan. Ons moet maar net gewoond raak".

Die resultate dui ook daarop dat die blanke verpleegkundiges van ontkenning gebruik maak: "Ek probeer nie te veel daaroor dink dat dit anders is nie, ek probeer maar net aangaan asof dit die hospitaal van drie jaar terug was".

Chrisman (1990:33) se siening van kultuurskok ondersteun die bevinding dat respondente kultuurskok beleef. Volgens Chrisman (1990:33) is kultuurskok "... that malady that occurs in response to transition from one setting to another, in which the individual is placed in an unfamiliar situation where former patterns of behavior are totally ineffective, and in which basic cues for social intercourse are absent". Dit blyk dat die respondente in kultuurskok is en daarom van ongesonde hanteringswyses soos vermyding. onttrekking en ambivalensie gebruik maak (Chrisman, 1990:34; Rambo, 1984:349; Keesing, 1981:301).

Die resultate van hierdie navorsing toon ook dat respondente (blanke verpleegkundiges en pasiènte) gesonde hanteringsmeganismes. soos in positiewe ingesteldheid reenoos en aanpassing by yerskillende bevolkingsproepe. en kulturele diversiteil 100 . Die positiewe ingesteldheid by respondente word gereflekteer in die volgende stellings: “... ek dink dit is ' $n$ wonderlike geleentheid. Veral as mens belangstel in die mens in al sy verskeidenheid, kan ons eie land baie meer waardeer want ons het so 'n ryke samestelling van volke in die land. Dit kan jou net laat groei en ontwikkel"; “... verrykend ... dit het vir my ' $n$ ander dimensie oopgemaak van ander bevolkingsgroepe", en "... you actually notice the difference in different personalities and 1 feel it actually enriches your own personality".

Aanpassing by verskillende bevolkingsgroepe en kulturele diversiteit deur die respondente word gedemonstreer deur die volgende: "Ek moes leer om persoonlik daarby aan te pas en tog my leefwyse so normaal as moontlik te hou"; Ek moes ' $n$ bietjie verander in hoe ek hulle benader, maar ek dink mens leer hulle tradisies ken ... hoe meer jy met hulle werk ... ander bevolkingsgroepe", en "In die begin het mens dit agtergekom, nou nie meer nie". Dit blyk dat hierdie respondente besig is om deur die aanpassingsfase van kultuurskok te beweeg (Chrisman, 1990:34; Rambo, 1984:349; Keesing, 1981:301).

\section{Emosionele belewenis van gesamentlike gesondheidsdienslewering aan alle bevolkingsgroepe}

Respondente verbaliseer hulle belewenis van ' $n$ verskeidenheid emosies, naamlik vreugde, woede/frustrasie, vrees en hartseer.

Vreugde word geverbaliseer deurrespondente landerskleurige verpleegkundiges en pasiënte) omdat daar nou gesamentlike gesondheidsdienslewering in hierdie hospitaal is. Die volgende stellings lig die belewenis van vreugde toe: "... it makes me very happy ... they care for all the people, treat us all together ... Because 1 can see they do everything for every patient in the same light"; "I enjoy their company. Why? Because they were also patient to me as I was patient to them:, en "... as alles so goed is, voel jy gelukkig en dan maak dit jou gou gesond". Die vreugde van die respondente kan moontlik, volgens Boonzaaier (1988:82) se siening, wees dat swartes bly is dat die apartheidsera verby is en dat hulle meer aanpasbaar en gemaklik is in " $n$ "anderskleurige" situasie.

Respondente (blanke verpleegkundiges en pasiente) het woede/frustrasie. vrees en hartseer geverbaliseer ien opsigte van gesamentlike gesondheidsdienslewering Die belewenis van woede en frustrasie deur respondente word gereflekteer in die volgende aanhalings: "My doelwit was om hierdie cenheid so gou as moontlik gestandaardiseer te kry en ek dink my oordeel was heeltemal te haastig gewees. Dit het my baie langer geneem as wat ek aanvanklik gedink het. My frustrasievlakke was geweldig hoog gewees"; "In die begin word "n mens kwaad want jy kom in die badkamer en dan het hulle langs die wasbak sommer die vloer gebruik vir 'n toilet", en "... intens geirriteer, hierdie harde geskreëry oor en weer veral met pasiënte, en dit maak dit moeilik om as sulks met hulle te werk". Die belewenis van vrees deur respondente handel oor $\mathrm{kwaliteit}$ pasiëntsorg en opleiding, sowel as persoonlike veiligheid. "Ek is baie bekommerd oor die kwaliteit van pasiëntsorg en die $k$ waliteit van opleiding wat hierdie studente behoort te kry"; "Ons word al hoe onveiliger in ons eie omgewing en dit maak dat 'n mens partykeer bekommerd voel en amper angstig voel"; "... it was fear when I saw the blacks and the Coloureds ...", en "... fear, I think of not really being able to relate to them, the fear of knowing that perhaps they are violent".

Hartseer gevoelens oor gesamentlike gesondheidsdienslewering is ook uitgespreek: “... ek kan amper sê, vreeslike depressie by my veroorsaak, in die sin dat ek nie geweet gaan ek regtig enigsins "n doelwit bereik nie" (verwys na opleiding van anderskleuriges); "Ek is jammer vir hulle en ek gee om vir hulle as persone", en "Hartseer, en 'n gevoel van ervaar hulle is gevoelloos, hulle gee nie om vir mekaar nie".

Die frustrasie/woede, vrees en hartseer wat deur respondente uitgespreek is, hou direk verband met hierdie respondent se persepsies ten opsigte van bevolkingsgroepe en kulture wat nie dieselfde as hulle $s$ ' $n$ is nie. Verwys na pp. 15-18 van hierdie artikel vir ' $n$ volledige bespreking in dié verband.

\section{Positiewe besluitneming ten opsigte van gesamentlike dienslewering}

Resultate van hierdie navorsing toon dat respondente (verpleegkundiges en pasiënte) positiewe besluite geneem het om die standaard van verpleging in stand te hou en deel te neem an die gesamentlike gesondheidsdienslewering: “... dit is teen my beginsels om 'n pasiënt op die vloer te verpleeg, ek is baie jammer. Ons gaan nie daardie standaarde van ons verlaag om dit te hanteer nie”; “... ek het verkies om hiernatoe te kom ... Ek was baie opgewonde met die wit verpleegsters ... want ek kyk as hulle met die pasiënte werk", en "At the time when I came over I was actually thinking of leaving nursing ... So I have been motivated ... you are given a chance to say what you like ... it makes you feel part of the hospital". Hierdie wedersydse respek getoon deur pasiënte en verpleegkundiges beinvloed die belewenis van kultuurskok direk en bespoedig aanpassing by die kulturele diverse gesamentlike gesondheidsdienslewering (Chrisman, 1990:35).

\section{SOSIALE DIMENSIE IN HOSPITAALOMGEWING}

Respondente beleef dat daar ' $n$ behoefte aan opvoeding by verpleegkundiges en pasiënte is en dat ondersteuningsbronne belangrik is in gesamentlike dienslewering aan alle bevolkingsgroepe. 
Respondente (blanke verpleegkundiges) verbaliseer eerstens dat anderskleurige pasiënte opgevoed behoort te word betreffende die gebruik van badkamergeriewe en higiëniese versorging: "Hulle weet niks .. langs die wasbak, sommer die vloer gebruik as toilet ... partykeer die wasbak as ' $n$ toilet gebruik", en " ... 'n groot leemte wat opvoeding aanbetref, wat higiëne en dié soort van ding betref." Soos reeds voorheen vermeld, is dit " $n$ onmoontlike verwagting van pasiënte wat nooit voorheen sanitêre geriewe en krane gehad het om vanself te weet hoe om daarmee om te gaan nie.

Van die respondente (blanke verpleegkundiges) meen dat daar opleidingsleemtes by hulle anderskleurige kollegas bestaan: "Toe ek die lêer oopmaak en daar is so ' $n$ sketsie van die maag op, kon sy nie die maag identifiseer nie", en "Verpleegdokumentering het hulle niks van geweet nie".

Respondente (verpleegkundiges) verbaliseer ook dat ondersteuningsbronne belangrik is in die gesamentlike gesondheidsdienslewering. Die eerste ondersteuningsbron wat hulle identifiseer, is dat daar goeie verpleegspansamewerking is: "Ons is ' $n$ fantastiese span wat saamwerk ... ons het nou net 'n heerlike werksgroep gevorm", en " ... the sisters all worked together". Chrisman (1990:34) meen dat aanpassing by veranderende kulturele omstandighede kulmineer tot ' $n$ effektiewe funksionerings-vlak waar persone saamwerk tot die bereiking van gesamentlike doelwitte.

in Leemte wat bestaan in die ondersteuningsbronne by hierdie hospitaal is dat daar geen opvolgstelsels vir ontslaande anderskleurige pasiënte is nie: "Ek ondervind ook dat daar baie min ondersteuningsmaatreëls in hulle gemeenskap is, wat vir my verskriklik is, dat hier ontslaan jy ' $n$ terminale pasiënt huis toe, maar daar is geen ondersteuningsfasiliteite in die gemeenskap nie", en "Binne die hospitaal vir die buitepasiënt is daar nie veel ondersteuningstelsels nie want die maatskaplike werker werk met binnepasiënte, sy gaan nie buite die hospitaal nie".

Die Herontwikkelingsprogram (RDP, ANC:1994) van die Regering van Nasionale Eenheid is juis daarop gemik om gemeenskapsfasiliteite daar te stel wat toeganklik is vir alle Suid-Afrikaners.

\section{GEESTELIKE DIMENSIE VAN DIE HOSPITAAL SE OMGEWING}

Die respondente verbaliseer die belang van hulle mensbeskouings, waardes en gewete in die gesamentlike gesondheidsdienslewering aan alle bevolkingsgroepe in die hospitaal. Wat die belang van mensbeskouing betref, val die fokus veral daarop dat daar geen verskil russen mense bestaan nie. respek wedersyds belangrik is en dat positiewe waardes lei tot aanvaarding. Die respondente lewer die volgende kommentaar omdat daar nie verskil tussen mense bestaan nie: "There is nothing for me being black. What is important, I am like other people. 1 do have feelings like other people ... it has made me aware when I am tampering in other peoples' feelings"; “ ... 'n mens sien volgens die persoon en etiketteer nie volgens velkleur ..."; "I really do not mind, because basically for me sick people are sick people", en "... hulle is tog dieselfde mense as ons. Hulle het dieselfde hart, hulle het dieselfde binnegoed as ons. Nou waarvoor kan hulle nie gesamentlik behandel word nie?".

Respek is ook belangrik volgens respondente: " ... wedersydse respek vir persone se individuele geloofsoortuigings en so aan ..."; " ... they respected me as a sister", en "They accepted me as an individual".

Positiewe waardes wat geverbaliseer is, is liefde, akkommodasie, vryheid en nieveroordeling van andersoortig mense: “... liefde vir medemens ... opdrag van God”; “... liefde vir jou medemens, meelewendheid, beteken vir my ook akkommoderend ..."; “ ... etiese norm handhaaf om respek te toon vir jou pasiënt se oortuigings"; " ... dit is "n vry land, en so, elke persoon doen sy ding op sy gebied", en "They might eat differently to me but I am not allowed to judge them".

Van die respondente (blanke verpleegkundiges) verbaliseer gewetenswroeging oor hulle onkunde betreffende anderskleuriges se leefwêreld: "Ek het nooit besef dat ... die gesondheidsfasiliteite is nie vir al die bevolkingsgroepe beskikbaar nie. Dit is vir my jammer dat daardie diskrepansie wel bestaan", en "Hulle hele maatskaplike opset pla my baie". Die laasgenoemde respondent verwys na die swak vervoerstelsel, geweld en min beskikbare gesondheidsdiensleweringhulpbronne vir anderskleuriges.

Uit bogenoemde bespreking blyk dit dat die respondente graag wedersydse respek vir ander bevolkingsgroepe wil toon sowel as liefde en aanvaarding. Hierdie wedersydse respek is ' $n$ kulturele bousteen en word gefundeer op die hoekstene van waardes, aanvaarding en geloof in ander (Boyle, 1989:54; Chrisman, in Patrick, 1991:36). Soos voorheen genoem, beïnvloed wedersydse respek die belewenis van kulturele diversiteit (Chrisman, 1990:35).

\section{KENMERKENDE WYSES VAN INTERAKSIE TUSSEN DIE VERSKILLENDE DIMENSIES VAN DIE HOSPITAAL SE OMGEWING}

Respondente is van mening dat daar kommunikasieprobleme bestaan en verbaliseer ook 'n sensitiwiteit teenoor moontlike diskriminasie in die gesamentlike gesondheidsdienslewering aan alle bevolkingsgroepe in die hospitaal.
Die kommunikasieprobleme ontstaan omdat verpleegkundiges en pasiënte nie in hulle moedertaal met mekaar kommunikeer nie kommunikasiestyle verskil, en misverstande ontstaan so: "If a person says 'I have heard", it means that you were talking, but he has not understood you. So you must make sure that a person has understood you, not heard what you are saying"; "Ek dring nie deur tot haar ("n anderskleurige kollega) nie. Ek kan nie"; “" ... 'n probleem met kommunikasie en daarom is dit partymaal frustrerend"; "There is still a wall, that unseen wall ... most of the whites are soft spoken, they do not want to speak aloud, you know, even if they give report ... they are not that audible"; “... 'n ding wat my geweldig irriteer, is dat as hulle hier kom sit ... hulle praat hulle eie taal"; “ ... ek kan nie lekker kommunikeer met die mense nie ... ek soek maar geselskap"; "Ek dink dit is waar vir my die grootste probleem lê ... dat ons nie hulle taal praat nie"; ".... we do have some problems, especially the language", en " ... dat werklik veertig persent van die pasiënte ons nie verstaan nie, nie Engels of Afrikaans magtig is nie ... 'n groot persentasie wat nie werklik verstaan wat met hulle gebeur nie en wat jy vir hulle sê nie".

Marais (1988) toon aan dat taalverskille ' $n$ aandeel het in kommunikasiegebreke aangesien Suid-Afrika oor ' $n$ diversiteit van tale beskik. Tans is daar elf amptelike tale in Suid-Afrika. Engels word as algemene medium van kommunikasie gebruik om kommunikasieprobleme die hoof te bied Butrin (1990:100) het bevind dat wanneer verpleegkundiges met pasiënte werk wat nie Engels magtig is nie, hulle aanneem dat hulle voor ontmoeting met die pasiënte reeds gefrustreerd sal wees omdat die pasiënt nie sal verstaan wat hulle sê nie.

Sensitiwiteit ten opsigte van diskriminasie word deur anderskleurige verpleegkundiges geverbaliseer: "Sometimes you tend to be treated, like with kid gloves and it is a bit rough when you have been nursing for a long time and someone starts treating you with kid gloves," en "You are not given enough opportunity to practise your skill ..."

As ' $n$ mens in ag neem dat die blanke verpleegkundiges openlik geverbaliseer het dat hulle kollegas se opleiding nie op standaard is nie is dit verstaanbaar dat hierdie houding wel anderskleuriges sal laat voel dat teen hulle gediskrimineer word en dat hulle nie die geleentheid gebied word om hulself te bewys nie - weer eens kom die houding "West is best" na vore.

\section{GEVOLGTREKKINGS}

Die belangrikste gevolgtrekkings wat voortvloei uit hierdie navorsing is:

- Die onvoldoende administratiewe struktuur in die hospitaal wat die gevolg is van onvoldoende voorbereiding tot gesamentlike gesondheidsdienslewering 
vir alle bevolkingsgroepe het tot gevolg dat verskeie probleme ontstaan. Hierdie probleme is onvoldoende oriëntering van pasiënte en verpleegkundiges; onvoldoende gesondheidspersoneel, en 'n verhoogde werkslading.

- Die blankes se persepsie ten opsigte van verskillende bevolkingsgroepe en persone van ander kulture is gevorm vanuit ' $n$ etnosentriese Westerse benadering. Dit lei tot hulle belewenis van kultuurskok wat gevoelens van woede/frustrasie, vrees en hartseer tot gevolg het.

- Die anderskleuriges se bereidwilligheid om aan te pas by gesamentlike gesondheidsdienslewering lei tot hulle belewenis van vreugde.

- Verpleegkundiges se aanvaarding van die gesamentlike gesondheidsdienslewering lei tot positiewe verpleegspansamewerking.

- Omdat verpleegkundiges en pasiënte nie in hulle moedertaal kan kommunikeer nie ontstaan kommunikasieprobleme. Taalprobleme en verskil in kommunikasiestyle (hard praat teenoor saggies praat) lei tot kommunikasieprobleme wat weer frustrasie tot gevolg het.

- Die Christelike mensbeskouings en waardes wat deur blanke verpleegkundiges en pasiënte geverbaliseer is, kom nie ooreen met hulle bevooroordeelde persepsie van persone uit ander bevolkingsgroepe en kulture nie.

- Daar bestaan onkunde by blankes en anderskleuriges oor mekaar se leefwêrelde wat lei tot vooroordele wat oop kommunikasie blokkeer.

\section{AANBEVELINGS}

Die volgende aanbevelings word op grond van die gevolgtrekkings van hierdie navorsing gemaak:

- Dit is belangrik dat deelnemende bestuur deel uitmaak van die administratiewe struktuur van hierdie hospitaal

- Voortdurende orièntasie van verpleegkundiges en pasiënte betreffende gesamentlike gesondheidsdienslewering aan alle bevolkingsgroepe is noodsaaklik. Geleentheid moet ook geskep word vir refleksie oor belewenisse in hierdie verband.

- Blanke verpleegkundiges se bevooroordeelde persepsies van ander bevolkingsgroepe en kulture behoort deur werksgroepe aangespreek te word.

- Verskillende meganismes om oop kommunikasie tussen bevolkingsgroepe in hierdie hospitaal te fasiliteer behoort geïdentifiseer en geïmplementeer te word.

- Konsultasie met taalkundiges vir die skep van meganismes om die taalvaardigheid van personeel te verbeter is noodsaaklik.

\section{ERKENNING}

Erkenning word gegee aan Medi-Clinic vir fmansiële ondersteuning in die voltooiing van hierdie navorsingsprojek.

\section{VEWYSINGS}

AFRICAN NATIONAL CONGRESS. (1994). The Reconstruction and development programme, a policy framework. Johannesburg: Uma-nyano Publications

BOONZAAIER, E. \& SHARP, J. (1988). South African keywords the uses and abuses of political concepts. Cape Town: David Philip.

BOYLE, J.S. \& ANDREWS, M.M. (1989). Transcultural concepts in nursing care. Glenview, Illinois: Scott, Foresman, Co

BURNS, N. \& GROVE, S.K. (1987). The practice of nursing research. Philadelphia: W.B. Saunders

BUTRIN, J.E (1990). The experience of culturally diverse nurse-client encounters. Unpublished $\mathrm{Ph} . \mathrm{D}$. thesis, Minnesota: University of Minnesota

CHRISMAN, N. (1990). Cultural shock in the operating room. Lournal of Transculural Nursing, 1(2):33-39.

CRESWELL, J.W. (1994). Research design qualitative and quantitative approaches Thousand Oaks, Califomia: Sage.

DöRFLING, P J.J. (1987). Die verwantskap tussen topbestuurwaardes en organisasiekultuur. Ongepubliseerde magisterverhandeling. Johannesburg: Randse Afrikaanse Universiteit.

DRENNAN, D. (1992). Tranforming company culture. London: McGraw-Hill

FRIEDMAN, I. (1995). Community based heatth care. Paper delivered at workshop 1 April 1995 Johannesburg Hospital: Johannesburg.

GIGER, J.N. \& DAVIDHIZAR, RE. (1991) Transcultural nursing. St. Louis: Mosby.

GILLIES, D.A. (1982). Nursing management. a systems approach. Philadelphia: W.B. Saunders

GIORGI, A. ed. (1985). Phenomenology and psychological research. Pittsburg. PA. Duquesne University Press.

KEESING, R.M. (1981). Culrural anthropology - a contemporary perspective. For Worth: Holt. Rinehar \& Winston

KERLINGER, F.N. (1986). Foundations of behavioral research, Chicago: Hott, Rinehar \& Winston

KOTZE, J.C. (1993). In their shoes, undenstanding black South Africans through their expenences of life. Cape Town: Juta.

KOTZ, W.J. (1990). Op weg na 2000: 'n uitdaging vir waagmoed en leierskap in die verplegingsberoep. Curationis, 13 (3) 4):65-76.

KREFTING, L. (1991). Rigor in qualitative research: the assessment of trustworthiness. The American Journal of Occupational Therapy. 45(3):214-222.

KVALE, S. (1983). The qualitative research review, a phenomenological and a hermeneutical mode of understanding. Journal of Phenomenological Psychology, 14:171-196.

LEININGER, M. (1991). Becoming aware of types of health practitioners and cultural imposition. Joumal of Transcultural Nursing, 2(2):32-39.

LINCOLN, Y.S. \& GUBA, E.G. (1985), Naturalistic Inquiry. Beverley Hills: Sage.

LUTHULI, N.D., MASIEA, S.E. \& ZUMA, L.C. (1992). The hurdles faced by black students. Nursing RSA Verpleging 7(2):30-33.

MARAIS, H.C. (1988). South Africa - perspective on the future. Pinetown: Owen Burgess.

MOUTON, J. \& MARAIS, H.C. (1990). Basiese begrippe, metodologie van die geestes-wetenskappe. Pretoria: Raad vir Geesteswetenskaplike Navorsing.

ORAL ROBERTS UNIVERSITY, (1990-1992). Catalog, School of Art and Sciences, Business, Education, Nursing and Theology and Missions, 17(1). Tulsa, Oklahoma: Oral Roberts University

PATRICK, WOODS, CRAVEN, ROKOSKY, BRUNO eds, (1991). Medical surgical nursing. pathophysiologic concepts. New York: Lippincott

POGGENPOEL, M., NOLTE, A., DöRFLING, C, GREEFF, M, GROSS, E., MüLLER, M. NEL, E. \& ROOS, S. (1994). Community views on informal housing environment, implications for health promotion. South African Joumal of Sociology. 25(4):131-136

POLIT, D.F. \& HUNGLER, B.P. (1989). Essentials of nursing research, methods appraisal, and utilization. Philadelphia: Lippincor.

RANDSE AFRIKAANSE UNIVERSITEIT, DEPARTEMENT VERPLEEGKUNDE. (1992). Verplegingsteorie vir Mensheelheid Aucklandpark: Randse Afrikaanse Universiteit.

RAMBO, B.J. (1984). Adaptation nursing. assessment and intervention. Philadelphia: W.B. Saunders.

WILSON, H.S. \& KNEISL, C.R. (1992). Psychiatric nursing. Redwood Ciry, California: Addison-Wesley.

Marie Poggenpoel, D.Phil.

(Verpleegkunde-Psigiatries) Professor, projekleier

Heilie Uys, D.Cur., Professor, medeprojekleier

Annatjie Botes, D.Cur., Medeprofessor

Minrie Greeff, D.Cur., Senior Lektor (ten tye van hierdie navorsingsprojek) Elna Gross, D.Cur., Senior Lektor Marie Müller, D.Cur., Professor

Anna Nolte, D.Litt et Phil.

(Verpleegkunde), Professor

Departement Verpleegkunde

Randse Afrikaanse Universiteit 